\title{
Suppression of leptin-induced hypothalamic JAK/STAT signalling and feeding response during pregnancy in the mouse
}

\author{
S R Ladyman, D M Fieldwick and D R Grattan \\ Department of Anatomy and Centre for Neuroendocrinology, School of Medical Sciences, University of Otago, \\ PO Box 913, Dunedin, New Zealand \\ Correspondence should be addressed to S R Ladyman; Email: sharon.ladyman@anatomy.otago.ac.nz
}

\begin{abstract}
Hyperphagia during pregnancy, despite rising concentrations of the satiety hormone leptin, suggests that a state of leptin resistance develops. This study investigated the satiety response and hypothalamic responses to leptin during pregnancy in the mouse. Pregnant (day 13) and nonpregnant mice received an i.p. injection of either leptin or vehicle and then 24-h food intake was measured. Further groups of pregnant and nonpregnant mice were perfused $2 \mathrm{~h}$ after leptin or vehicle injections and brains were processed for pSTAT3 and PSTAT5 immunohistochemistry. Leptin treatment significantly decreased food intake in nonpregnant mice. In pregnant mice, however, leptin treatment did not suppress food intake, indicating a state of leptin resistance. In the arcuate nucleus, leptin treatment increased the number of cells positive for PSTAT3, a marker of leptin activity, to a similar degree in both nonpregnant and pregnant mice. In the ventromedial nucleus (VMN), the leptin-induced increase in pSTAT3-positive cell number was significantly reduced in pregnant mice compared to that in nonpregnant mice. In nonpregnant mice, leptin treatment had no effect on the number of pSTAT5-positive cells, suggesting that in this animal model, leptin does not act through STAT5. In pregnant mice, basal levels of pSTAT5 were higher than in nonpregnant mice, and leptin treatment led to a decrease in the number of pSTAT5-positive cells in the hypothalamus. Overall, these results demonstrate that during pregnancy in the mouse, a state of leptin resistance develops, and this is associated with a reduced sensitivity of the VMN to leptin.

Reproduction (2012) 144 83-90
\end{abstract}

\section{Introduction}

Pregnancy is characterised by an increase in food intake to meet the energy demands of the growing foetus and also to prepare for the subsequent demands of lactation. The increase in food intake during pregnancy is a very topical issue, stemming from the increasing prevalence of obesity in recent years. Obesity during pregnancy is a serious health issue that increases the risk for obstetric complications and serious congenital abnormalities and can predispose the offspring to childhood obesity (Oken et al. 2007, Stothard et al. 2009, Flick et al. 2010).

Leptin, the hormone product of the $o b$ gene, plays an integral part in the regulation of energy balance. Leptin is secreted in proportion to body fat levels and acts in the hypothalamus to suppress appetite and increase metabolic rate (Campfield et al. 1995, Halaas et al. 1995, Pelleymounter et al. 1995). The effects of leptin are mediated through the leptin receptor $(\mathrm{Ob}-\mathrm{R})$, a member of the class I cytokine receptor family (Tartaglia et al. 1995). Within the hypothalamus, expression of the long form of the Ob-Rz, the only receptor isoform capable of full signal transduction, has been detected in significant amounts in the arcuate nucleus, ventromedial $(\mathrm{VMN})$, dorsomedial and paraventricular hypothalamic nuclei (PVN; Mercer et al. 1996). While leptin activates many intracellular signal transduction pathways, the most well characterised and essential for the effects of leptin on energy homeostasis involves a JAK/STAT pathway (Bates et al. 2003). Once leptin binds to its receptor, the receptor-associated JAK proteins become phosphorylated, which in turn leads to the phosphorylation of the Ob-Rz and the creation of binding sites for cytoplasmic STAT. Once bound to the receptor, STAT molecules are phosphorylated, dimers are formed and then translocated to the nucleus where they modify gene transcription. There are currently seven members of the STAT family (Darnell 1997), and it is well established that in the hypothalamus, leptin acts through STAT3 to suppress food intake (Bates et al. 2003). There is also some indication that leptin may also signal through STAT5 within the hypothalamus (Gong et al. 2007, Mutze et al. 2007), although leptin-induced phosphorylation of STAT5 in the hypothalamus is not observed in all studies (Vaisse et al. 1996, McCowen et al. 1998, Rizk et al. 2001).

As part of the gestational changes in the hormonal environment, leptin concentrations are increased during 
pregnancy (Gavrilova et al. 1997, Tomimatsu et al. 1997, Mistry \& Romsos 2002). The pregnancy-induced increase in food intake and leptin concentrations have led to the hypothesis that the brain becomes insensitive to the satiety actions of leptin during pregnancy. Pregnant rats no longer show a satiety response to an exogenous dose of leptin, supporting the hypothesis that pregnancy is a state of leptin resistance and that this is associated with a decreased ability of leptin to activate the JAK/STAT signalling pathway in the VMN (Ladyman \& Grattan 2004, 2005). Given the prevalence of transgenic mouse models in the study of leptin regulation of food intake, the aim of the current study was to examine whether mice develop a state of leptin resistance during pregnancy. Both the satiety response to leptin and ability of leptin to activate JAK/STAT signal transduction in the hypothalamus were used as measures of leptin sensitivity.

\section{Results}

\section{Food intake, body weight and leptin concentrations during pregnancy}

Daily food intake before, during and after pregnancy is shown in Fig. 1A. Twenty-four-hour food intake in nonpregnant virgin mice averaged $3.7 \mathrm{~g}$. In pregnant mice, food intake increased and was significantly higher than in nonpregnant mice by day 10 of pregnancy. Consumption peaked at days 15 and 16 of pregnancy and dropped significantly the day before parturition. Food intake further increased in early lactation mice to an amount significantly greater than in both nonpregnant and pregnant mice. Body weight steadily increased in pregnant mice and was significantly greater than in nonpregnant mice by day 8 (Fig. 1B). Following parturition, during early lactation in mice, body weight remained significantly increased compared with virgin mice, although significantly reduced compared with late pregnancy. Leptin concentrations were significantly higher in day 13 pregnant mice compared with nonpregnant mice $(2.63 \pm 0.7$ vs $1.02 \pm 0.1 \mathrm{ng} / \mathrm{ml}$, $n=5$ per group).

\section{Feeding response to leptin}

In the $24 \mathrm{~h}$ before fasting, food intake was $\sim 25 \%$ greater in pregnant mice compared with nonpregnant mice; however, when this is adjusted for body weight, food intake was no longer significantly increased in the pregnant group. Leptin-treated nonpregnant mice showed a significant reduction in 24-h food intake compared with vehicle-treated nonpregnant mice (Fig. 2). During pregnancy, leptin treatment did not significantly reduce food intake compared with the vehicle-treated group (Fig. 2). When food intake was not normalised to body weight, a similar result was
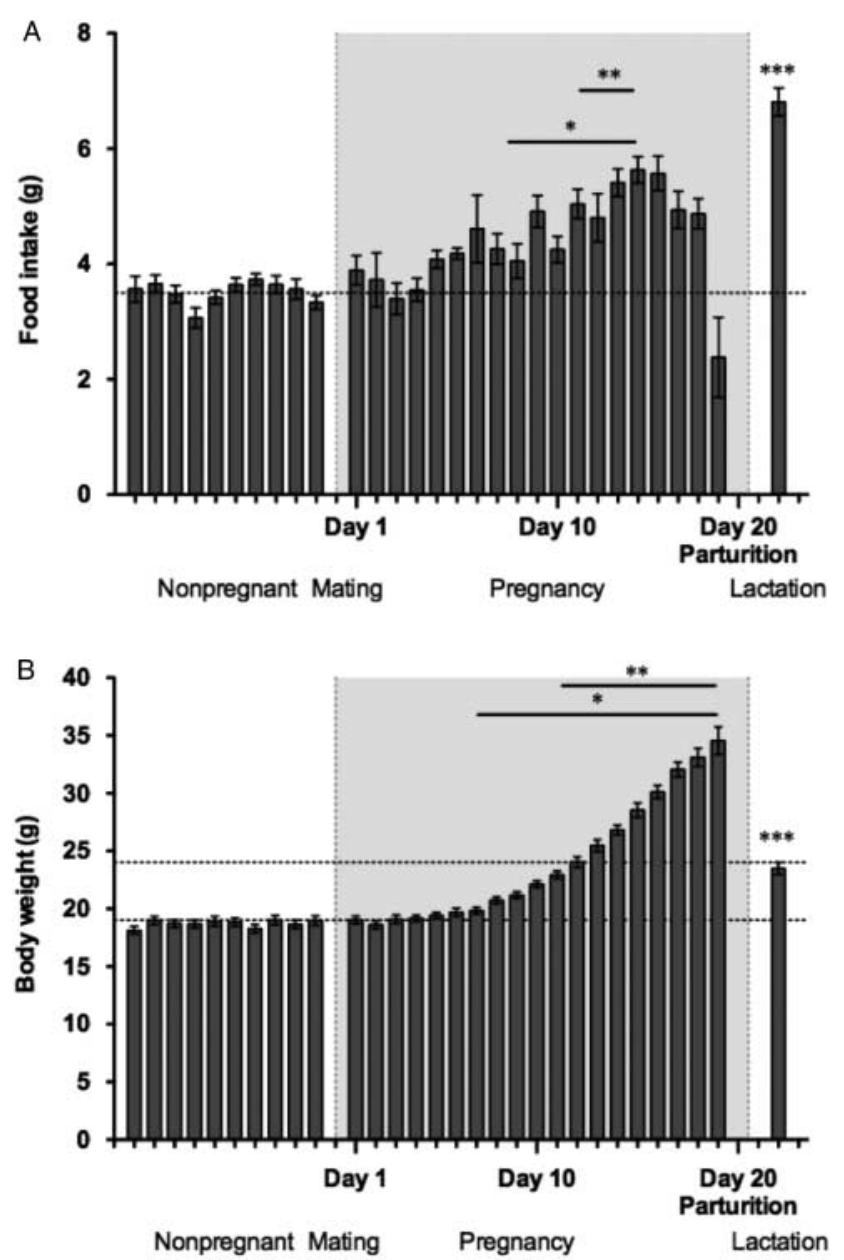

Figure 1 Bars represent the mean \pm S.E.M. daily food intake (A) and body weight $(\mathrm{B})$ during the oestrous cycle $(n=12)$, pregnancy $(n=10)$ and early lactation in mice $(n=7)$. The duration of pregnancy was 19 days (shaded area) with parturition on day 20. Data bars are absent where data were not collected. *Significant with respect to food intake during the oestrous cycle $(P<0.05)$. ${ }^{*}$ Significant with respect to early pregnancy $(P<0.05)$. ***Significant with respect to virgin and pregnant mice $(P<0.05)$. The dotted line indicates the average levels in the nonpregnant state (a) and in both the nonpregnant and pregnant states (b).

observed; nonpregnant mice responded to leptin with reduced food intake while pregnant mice did not. Nonpregnant and pregnant mice ate significantly more following an overnight fast compared with the $24 \mathrm{~h}$ before fasting, showing a fasting-induced hyperphagic response. In response to fasting, both nonpregnant and pregnant mice consumed a similar amount $(\sim 3 \mathrm{~g})$ more than their normal, nonfasted food consumption level. As nonpregnant mice lost proportionally more body weight during the fasting period compared with pregnant mice, when food intake was normalised to body weight, this gave the impression of a greater post-fasting hyperphagic response. However, in terms of absolute food consumption, the increase in response to fasting was similar in both the groups. 


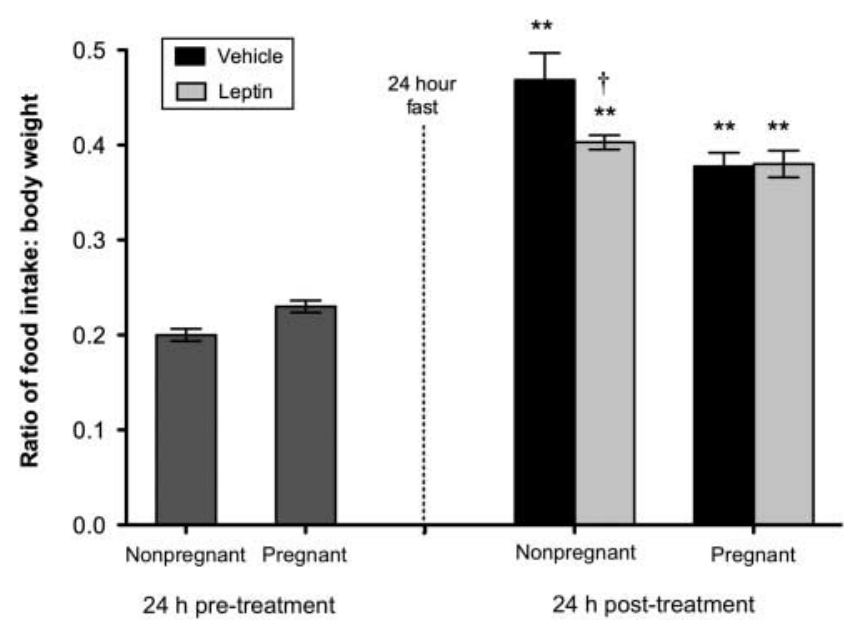

Figure 2 Bars represent the mean \pm s.E.M. 24-h food intake normalised to body weight in nonpregnant and pregnant mice before fasting and following leptin or vehicle i.p. injection. Injections were given on day 13 of pregnancy or dioestrus, $1 \mathrm{~h}$ before the start of the dark phase. **Significant with respect to pre-fasting $24-\mathrm{h}$ food intake in the same group $(P<0.05)$. ${ }^{\dagger}$ Significant with respect to vehicle-treated group of the same physiological state $(P<0.05) . n=7-5$ per group.

\section{Hypothalamic PSTAT3 expression after leptin treatment}

In the arcuate nucleus, leptin treatment significantly increased the number of pSTAT3-positive cells in both nonpregnant and day 13 pregnant mice (Fig. 3). The number of leptin-induced pSTAT3-positive cells was similar in both physiological states (Fig. 3). In the VMN, leptin treatment significantly increased the number of pSTAT3-positive cells compared with the vehicle-treated group in both physiological states (Fig. 3). However, in the pregnant group, the number of pSTAT3-positive cells following leptin treatment was significantly reduced compared with the leptin-treated nonpregnant group.

In the PVN, only very low levels of PSTAT3 were observed. In nonpregnant mice, leptin treatment significantly increased the number of pSTAT3-positive cells in the PVN compared with vehicle treatment $(9.2 \pm 0.8$ vs $2 \pm 1.2$ cells per section). However, leptin treatment did not lead to an increase in the number of pSTAT3-positive cells in the pregnant mice $(1.3 \pm 0.5 \mathrm{vs} 2.7 \pm 1.0$ cells per section).

\section{Hypothalamic PSTAT5 expression after leptin treatment}

Very few PSTAT5-positive cells were observed in the arcuate nucleus, VMN and PVN of vehicle-treated nonpregnant mice, and leptin treatment failed to increase the number of cells positive for PSTAT5 (Figs 4 and 5). Pregnant vehicle-treated mice had high levels of PSTAT5 in the arcuate nucleus, VMN and PVN regions of the hypothalamus compared with nonpregnant mice (Figs 4 and 5). Leptin treatment during pregnancy resulted in a significant decrease in the number of cells positive for PSTAT5 in the arcuate nucleus and VMN (Fig. 4) and also in the PVN (Fig. 5).

In the VMN of pregnant mice, the distribution of pSTAT5- and pSTAT3-positive cells was noticeably quite different, with pSTAT5 cells clustered in the lateral regions of the VMN (Fig. 4) while pSTAT3 cells were located in the medial portion of this area (Fig. 3). In the PVN, only a very low number of pSTAT3-positive cells were detected, while PSTAT5 was more abundant in this area (Fig. 5).

\section{Discussion}

The maintenance of a successful pregnancy places great demands on the resources of the mother. Changes in appetite and metabolism are a key feature of pregnancy
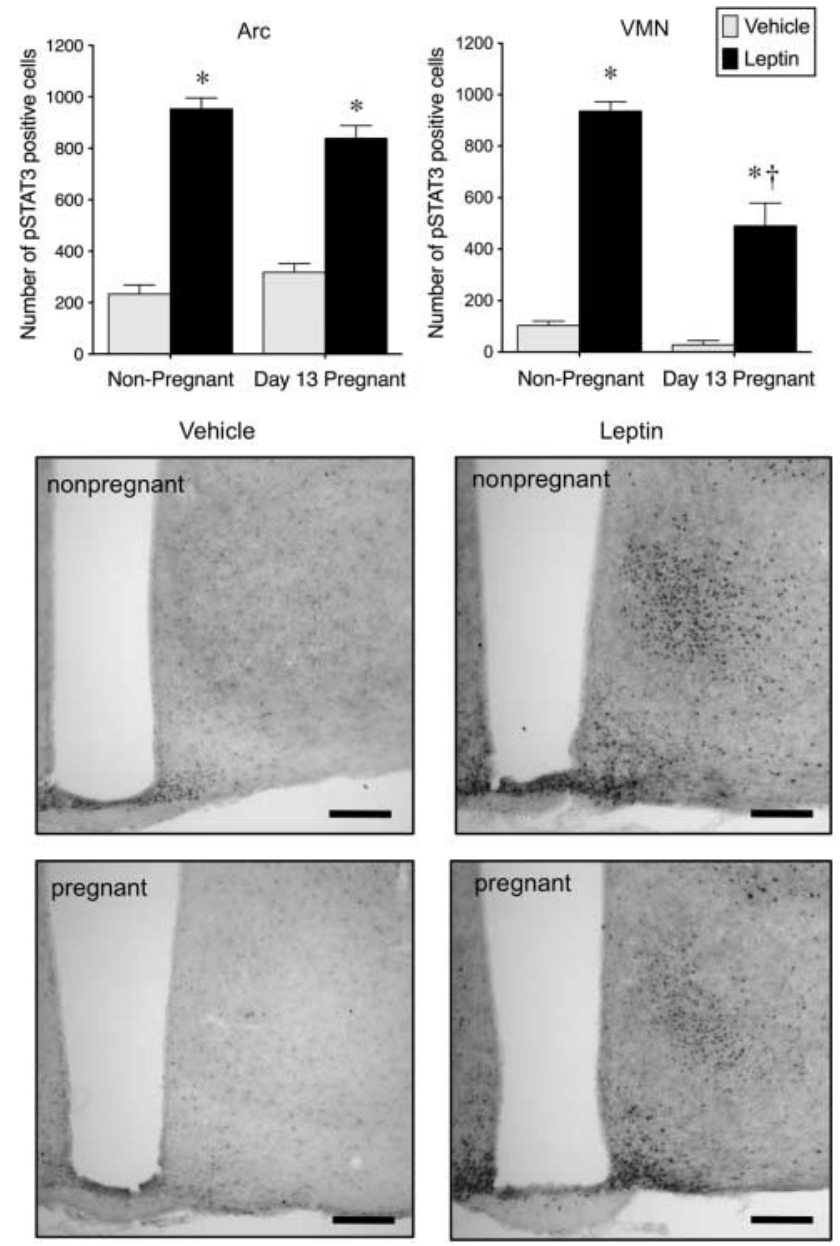

Figure 3 Bars represent the mean \pm S.E.M. number of pSTAT3-positive cells in the arcuate nucleus and VMN $2 \mathrm{~h}$ after leptin or vehicle administration (i.p.) in nonpregnant and pregnant mice $(n=5-6$ per group). Images show PSTAT3 staining in representative coronal sections of the medial basal hypothalamus $2 \mathrm{~h}$ after vehicle or leptin i.p. injection in nonpregnant and pregnant mice. *Significant with respect to vehicle treated-group of same physiological state $(P<0.05)$. ${ }^{+}$Significant with respect to leptin-treated nonpregnant group $(P<0.05)$. Scale bars $=100 \mu \mathrm{m}$. 


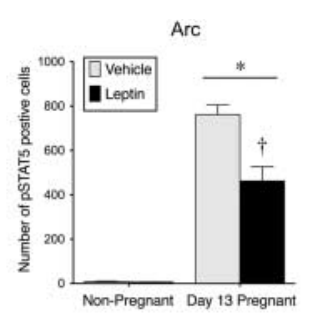

Vehicle
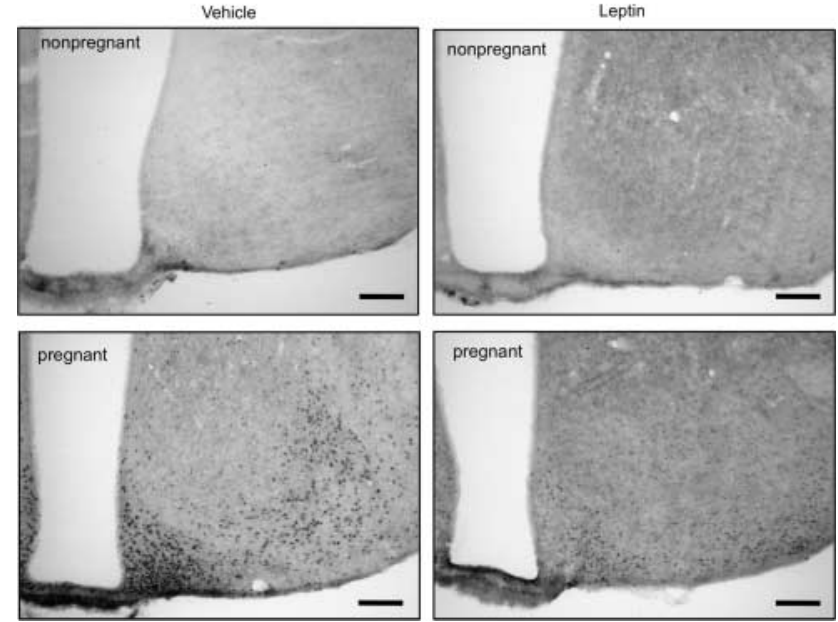

Figure 4 Bars represent the mean \pm S.E.M. number of pSTAT5-positive cells in the arcuate nucleus and VMN $2 \mathrm{~h}$ after leptin or vehicle administration (i.p.) in nonpregnant and pregnant mice $(n=5-6$ per group). Images show PSTAT5 staining in representative coronal sections of the medial basal hypothalamus $2 \mathrm{~h}$ after vehicle or leptin i.p. injection in nonpregnant and pregnant mice. *Significantly different to nonpregnant group $(P<0.05)$. ${ }^{+}$Significant with respect to vehicle-treated group of same physiological state $(P<0.05)$. Scale bars $=100 \mu \mathrm{m}$.

in mammals. These adaptations are required to meet the demands of pregnancy, which are ensuring the growth and development of the foetus, including the deposition of energy stores of the foetus and preparing the maternal body with adequate energy reserves for the subsequent period of lactation. By day 13 of pregnancy, food intake is increased despite rising leptin concentrations, suggesting a state of leptin resistance. Results from this study also demonstrate that during pregnancy in the mouse, i.p. leptin administration does not reduce food intake as it does in nonpregnant mice and that leptininduced phosphorylation of STAT3 is significantly less in the $\mathrm{VMN}$ and PVN of pregnant mice compared with nonpregnant mice. These results further support the hypothesis that during pregnancy, a state of leptin resistance develops in the mouse, and this is likely to help the body to overcome the normal feedback constraints of leptin and hence facilitate the increase in food intake and fat deposition during pregnancy. Furthermore, these results extend previous knowledge by demonstrating that during pregnancy in the mouse, specific areas of the hypothalamus show reduced sensitivity to leptin while the arcuate nucleus remains responsive to leptin.
Daily food intake was shown to increase in pregnant mice and was significantly higher than that in nonpregnant mice by day 10 of pregnancy. Leptin has been shown to increase by mid pregnancy in the mouse (Gavrilova et al. 1997, Tomimatsu et al. 1997, Mistry \& Romsos 2002), so the high levels of leptin alongside the increased food intake suggest a state of leptin resistance during pregnancy in the mouse. Furthermore, in $o b / o b$ mice, which lack endogenous leptin but have undergone daily leptin treatment to restore reproductive function,
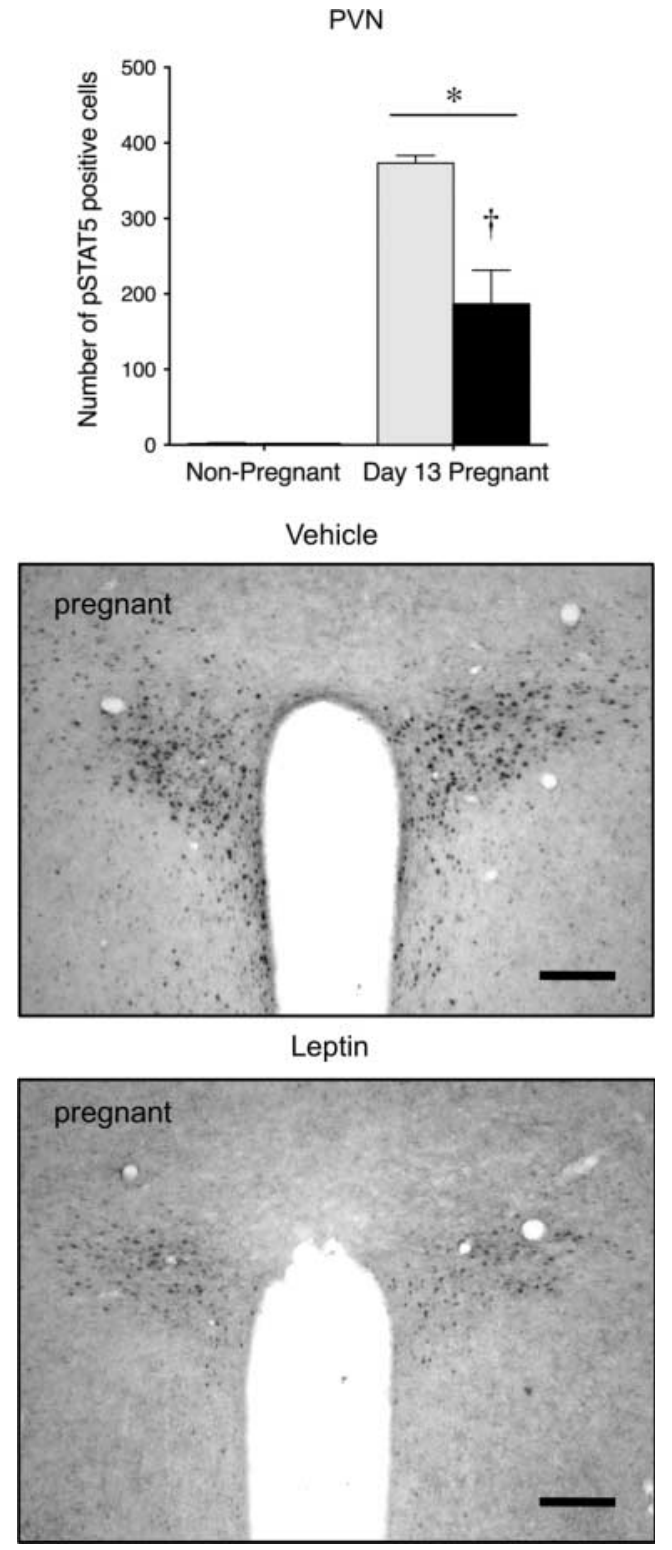

Figure 5 Bars represent the mean \pm S.E.M. number of pSTAT5-positive cells in the PVN 2 h after leptin or vehicle administration (i.p.) in nonpregnant and pregnant mice ( $n=6-5$ per group). Images show pSTAT5 staining in representative coronal sections of the PVN $2 \mathrm{~h}$ after vehicle or leptin i.p. injection in nonpregnant and pregnant mice. *Significantly different to nonpregnant group $(P<0.05)$. ${ }^{\dagger}$ Significant with respect to vehicle-treated group of same physiological state $(P<0.05)$. Scale bars $=100 \mu \mathrm{m}$. 
these daily injections of leptin do not prevent pregnancyinduced hyperphagia, also suggesting that a state of leptin resistance develops (Mounzih et al. 1998). The results from the current study demonstrating the inability of exogenous leptin to decrease 24-h food intake during pregnancy further supports this hypothesis. However, it is not clear whether pregnancy-induced leptin resistance is due to central or peripheral leptin resistance or both.

During pregnancy in the mouse, it has been suggested that leptin access into the brain is impaired due to an increase in leptin-binding proteins in the blood (Gavrilova et al. 1997). Further support for this hypothesis comes from the report that food intake is decreased in pregnant mice following central administration of leptin (Mistry \& Romsos 2002). In the current experiment, the fact that the arcuate nucleus presents normal leptin-induced STAT3 phosphorylation during pregnancy suggests that transport into the brain is not significantly compromised. The underlying cause of the decrease in leptin-induced STAT3 phosphorylation in the VMN and PVN is unknown but could include decreases in the Ob-Rz, as has been demonstrated in the VMN in pregnant rats (Ladyman \& Grattan 2005) or increases in inhibitory molecules of the JAK/STAT pathway such as SOCS or PTP1B, which have been seen in diet-induced (Bjorbaek et al. 1998, Munzberg et al. 2004, White et al. 2009) or age-induced leptin-resistant animals (Peralta et al. 2002, Morrison et al. 2007).

Alternatively, it could be concluded that leptininduced phosphorylation of STAT3 in the arcuate nucleus is unchanged during pregnancy because unlike other areas of the hypothalamus, the arcuate nucleus contains leptin-sensitive neurons that project outside the blood-brain barrier (Faouzi et al. 2007). Therefore, it could be hypothesised that decreased transport of leptin into the brain may not affect leptin signal transduction in the arcuate nucleus to the same degree as other hypothalamic areas. In contrast to the arcuate nucleus, the VMN and PVN had decreased leptin sensitivity during pregnancy, and these areas would be predicted to be more vulnerable to impaired accessibility of leptin into the brain (Munzberg 2008). However, only a subpopulation of leptin-responsive arcuate nucleus neurons have direct contacts with circulating concentrations of leptin (Faouzi et al. 2007), and hence, these cannot account for all the leptin-responsive cells in the arcuate nucleus observed during pregnancy. It is possible that there are both peripheral and central components in pregnancy-induced leptin resistance in the mouse. While leptin-induced pSTAT3 was normal in the arcuate nucleus during pregnancy, it is possible that pregnancyinduced leptin resistance in this nucleus could involve impairments in alternative intracellular signalling pathways or later events in the JAK/STAT signalling pathway, or pathways downstream of first-order leptinresponsive neurons. For example, in the pregnant rat, leptin resistance is associated with relatively normal leptin sensitivity in the arcuate nucleus (Ladyman \& Grattan 2005), but an inability of the melanocortin system, a downstream neural pathway of arcuate nucleus first-order leptin-responsive neurons, to decrease food intake (Ladyman et al. 2009).

The immunohistochemistry results for leptin-induced pSTAT3 suggest a central component of leptin resistance during pregnancy in the mouse; however, previously, it has been shown that pregnant mice are able to respond to i.c.v. leptin administration with a decrease in food intake (Mistry \& Romsos 2002). One explanation for this is the doses used in the different studies. The i.p. leptin dose used to examine the sensitivity of first-order leptinresponsive neurons was a sub-threshold dose in terms of the effect on food intake while the i.c.v. dose used previously (Mistry \& Romsos 2002) was a high dose that has been shown to maximally decrease food intake (Mistry et al. 1997). Therefore, this large dose may mask any possible changes in sensitivity. Alternatively, it is possible that the different states of fasting during pregnancy lead to changes in the sensitivity to leptin. In the current study, mice were fasted overnight and all experienced a post-fasting hyperphagia, while in the experiment by Mistry \& Romsos (2002), mice were only fasted for $4 \mathrm{~h}$ and it is unknown whether they exhibited a post-fasting hyperphagia. It is possible that under the increased metabolic stress, fasting pregnant mice may become less sensitive than nonfasting pregnant mice to any suppression of appetite by leptin in an attempt to protect their state of positive energy.

As well as STAT3, leptin-induced phosphorylation of STAT5 was investigated in pregnant mice. There are conflicting data as to whether leptin treatment leads to the phosphorylation of STAT5 in the hypothalamus and hence whether this molecule is involved in hypothalamic leptin signal transduction (Vaisse et al. 1996, McCowen et al. 1998, Rizk et al. 2001, Gong et al. 2007, Mutze et al. 2007). Using immunohistochemistry to detect phosphorylated STAT5, there was no difference in the number of pSTAT5-positive cells in the VMN, arcuate nucleus or PVN in vehicle- and leptin-treated nonpregnant mice. Therefore, in this animal model, it appears that leptin does not signal through STAT5 in these hypothalamic areas. In contrast to the low levels of pSTAT5 in the hypothalamus of dioestrous mice, much higher levels of PSTAT5 were observed in the hypothalamus during pregnancy. Within the hypothalamus, phosphorylation of STAT5 is induced by prolactin (Brown et al. 2010) and GH (Bennett et al. 2005). Placental lactogen, which is very closely related to prolactin, is high during pregnancy (Soares et al. 1991, Grattan 2001) and the high levels of this hormone are likely to account for the high pSTAT5 levels during pregnancy.

Interestingly, in the pregnant mice, leptin treatment led to a decrease in the number of pSTAT5-positive cells in the arcuate nucleus, VMN and PVN. The mechanism 
underlying this unexpected reduction and the functional outcome of this decrease are unknown. One hypothesis is that as both prolactin and leptin signal via JAK/STAT signalling pathways, the leptin treatment activates potential negative regulators of the JAK/STAT signalling cascade, such as SOCS proteins, which then inhibit phosphorylation of STAT5. However, evidence would suggest that this is unlikely. First, in cultured cells, it has been shown that high doses of leptin have no effect on the ability of prolactin to induce pSTAT5 phosphorylation (Roy et al. 2007). Secondly, this interaction would require leptin and prolactin to act on the same cells and this is yet to be demonstrated. While double-label immunohistochemistry for PSTAT3 and pSTAT5 has not been carried out, the patterns of staining in the singlelabel immunohistochemistry observed in the current study and previous examples (Ladyman et al. 2010) suggest that there is little overlap in the leptin-responsive and prolactin-responsive neurons. Thus, it seems unlikely that action on the prolactin-responsive neurons is directly causing the reduction in pSTAT5 after leptin treatment during pregnancy. It is also unlikely that leptin treatment directly leads to a decrease in placental lactogen concentrations as in vitro studies have shown that leptin has no effect on the secretion of placental lactogen from the placenta (Coya et al. 2006, Fuglsang et al. 2008). Both leptin and prolactin are thought to enter the brain by active, saturable transport mechanisms, and it is tempting to speculate about possible competition between leptin and prolactin for entry into the brain. There is currently insufficient knowledge about the transport of these hormones into the brain to support this hypothesis. Whatever the mechanism of leptin-induced reductions in the phosphorylation of STAT5, they appear to be specific to pregnancy. The decrease in PSTAT5 following leptin treatment during pregnancy is quite an unexpected result and warrants further investigation.

In conclusion, the current study demonstrates that in the mouse, a state of leptin resistance develops during pregnancy and that this is associated with a reduction in the ability of leptin to phosphorylate STAT3 in the VMN and the PVN. This may be caused by impaired access of leptin into the CNS or central mechanisms such as a reduction of Ob-Rs similar to what is observed in the rat (Ladyman \& Grattan 2005). At this time, the sensitivity of the arcuate nucleus was unaffected in terms of leptininduced pSTAT3, and given the importance of the arcuate nucleus in the satiety effects of leptin, this suggests a possible downstream, a central component in the mechanisms underlying leptin resistance. Interestingly, these results are different to leptin-resistant obese mice that show an impaired pSTAT3 response to leptin specifically in the arcuate nucleus (Munzberg et al. 2004), suggesting different mechanisms underlying pregnancy-induced leptin resistance and leptin resistance observed during obesity (Ladyman 2007).
The results from this study also show an inability of leptin treatment to phosphorylate STAT5 in the hypothalamus and a novel role for leptin to decrease hypothalamic pSTAT5 specifically during pregnancy.

\section{Materials and Methods}

\section{Animals}

Adult female C57BL/6J mice (age 7-9 weeks, weighing 17-20 g) were obtained from the University of Otago's colony at the Taieri Resource Unit. Mice were individually housed in a temperature- and lighting-controlled environment $\left(22 \pm 1{ }^{\circ} \mathrm{C}\right.$, $12 \mathrm{~h}$ light:12 $\mathrm{h}$ darkness) and allowed access to food and water ad libitum except during fasting when only water was available. For the nonpregnant mice, the oestrous cycle was monitored by daily cytological examinations of vaginal smears. To generate timed pregnancies, female mice were paired with a male until pregnancy was confirmed by the presence of a mucous plug in the morning following mating (day 1 of pregnancy). The day of parturition was considered as day 1 of lactation. All experimental protocols were approved by the University of Otago Animal Ethics Committee.

\section{Food, leptin and body weight measurements during pregnancy}

Daily food intake and body weight were measured in female mice $(n=12)$ for 15 days before mating and for the duration of pregnancy. Two mice did not become pregnant, and hence, data were only collected from ten mice from conception onwards. Food intake was not measured on the day of mating due to the presence of male mice nor was it measured on the day of parturition or the following day to avoid interfering with the establishment of maternal behaviour. Another group of mice was killed on either dioestrus $(n=5)$ or day 13 of pregnancy $(n=5)$, and truck blood was collected. Leptin concentrations were measured in plasma samples using a commercially available ELISA kit (Mouse leptin ELISA Kit no. EZML-82K; Millipore Corporation, Billerica, MA, USA).

\section{Feeding response to leptin}

The feeding response to i.p. leptin administration was determined in nonpregnant (dioestrous) and mid pregnant (day 13) mice. For all animals, 24-h food intake was monitored for 3 days before the beginning of the experiment to ensure normal food intake levels. On day 12 of pregnancy or metoestrus, mice were fasted overnight. Fasting was necessary for this experiment to ensure that all the groups had equivalent low endogenous leptin concentrations at the time of leptin injection. After fasting, half of the mice were randomly selected to receive a $0.2 \mathrm{ml}$ injection of recombinant mouse leptin $(10 \mathrm{mg} / \mathrm{kg}$ BW, leptin obtained from the National Hormone and Peptide Program (NHPP), NIDDK and Dr Parlow), diluted in saline, and the remaining animals received the same amount of vehicle (saline). Preliminary data indicated that a higher dose was required to see a significant decrease in 24-h food intake following a single i.p. leptin injection compared with the 
phosphorylation of hypothalamic STAT3 by leptin. Preweighed food pellets were returned at the time of injection and food intake was measured $24 \mathrm{~h}$ later.

\section{Leptin-induced signal transduction during pregnancy}

On day 12 of pregnancy or metoestrus for the nonpregnant mice, $1 \mathrm{~h}$ before the dark phase, food was removed from the cages and mice were fasted overnight. After fasting for $\sim 16 \mathrm{~h}$, all the mice received an i.p. injection of leptin (1 mg/kg BW) or vehicle (saline). Two hours after injections, mice were anaesthetised with a single i.p. injection of pentobarbital $30 \mathrm{mg} / \mathrm{ml}$ and intracardically perfused with cold $4 \%$ paraformaldehyde in $0.1 \mathrm{M}$ phosphate buffer $\left(4^{\circ} \mathrm{C}\right.$, $\mathrm{pH}$ 7.3). The brains were removed and post-fixed using the same fixative overnight at $4{ }^{\circ} \mathrm{C}$ and then soaked in sucrose solution (30\% sucrose in $0.1 \mathrm{M}$ phosphate buffer) at $4{ }^{\circ} \mathrm{C}$ until the brains had sunk. Coronal sections $(30 \mu \mathrm{m})$ were cut on a microtome $\left(-20{ }^{\circ} \mathrm{C}\right)$ through the hypothalamus and collected in three series, each containing sections $\sim 90 \mu \mathrm{m}$ apart. Sections were stored in cryoprotectant at $-20{ }^{\circ} \mathrm{C}$ until further processing.

\section{Immunohistochemistry}

One series of sections from the hypothalamus was processed for immunohistochemistry using a pSTAT3-specific antibody (\#9145 Cell Signaling Technology, Inc., Beverly, MA, USA). After removal from cryoprotection, sections were washed three times in $\mathrm{TBS} / 0.1 \%$ Tween 20. Sections were then incubated for $15 \mathrm{~min}$ in sub-boiling $1 \mathrm{mM}$ EDTA ( $\mathrm{pH}$ 8.0) and then incubated at room temperature in $0.3 \% \mathrm{H}_{2} \mathrm{O}_{2}$ for $10 \mathrm{~min}$ to block endogenous peroxidases. Following this, sections were then incubated in blocking buffer (TBS/0.1\% Tween 20, $3 \% \mathrm{BSA}$ and $3 \%$ normal goat serum) at room temperature for $1 \mathrm{~h}$ and then incubated overnight at $4{ }^{\circ} \mathrm{C}$ in blocking solution containing the pSTAT3 antibody (1:1000 dilution). The next day, the sections were incubated in a biotinylated secondary goat anti-rabbit antibody for $1 \mathrm{~h}$ at room temperature $(1: 1000$ diluted in blocking solution without BSA) and then with an avidin-biotin-peroxidase complex (Vectastain Elite ABC kit; Vector Laboratories, Peterborough, UK) for $1 \mathrm{~h}$. The peroxidase signal was visualised using 3,3'-diaminobenzidine (nickel-intensified substrate kit from Vector Laboratories). This reaction was stopped by three 10-min incubations in TBS. Sections were mounted on gelatin-coated slides and, once dry, slides were dehydrated through an alcohol series ending with two 20-min xylene incubations. Slides were coverslipped with DPX.

Immunohistochemistry using a pSTAT5 (pSTAT5 Tyr 694; Cell Signaling Technology, 1:500 dilution)-specific antibody was performed on a second series of sections as described previously (Brown et al. 2010). Sections underwent an antigen retrieval step consisting of incubation in $0.01 \mathrm{M}$ Tris- $\mathrm{HCl}(\mathrm{pH}$ 10) at $90^{\circ} \mathrm{C}$ for $5 \mathrm{~min}$. The primary antibody incubation was carried out at $4{ }^{\circ} \mathrm{C}$ for $\sim 72 \mathrm{~h}$ and the secondary antibody (biotinylated goat anti-rabbit, 1:200 dilution; Vector Labs) incubation was at RT for $90 \mathrm{~min}$.

\section{Immunohistochemistry analysis}

For the immunohistochemistry analysis, at least four sections per area from each animal were counted, and all analysis was performed blind to treatment group. The sections were photographed using an Olympus BX51 research microscope $(10 \times$ objective) and an attached digital camera. The areas of interest (arcuate nucleus, VMN and PVN) were defined using the mouse brain atlas (Paxinos \& Franklin 2004). In each area of interest, the total number of positively stained cells within defined boundaries on both sides of the ventricle was counted using the particle-counting function in Image J software (NIH) as described previously (Ladyman \& Grattan 2005). Data are presented as the mean number of pSTAT3- or pSTAT5-positive nuclei per section in each group \pm s.E.M. to show the mean levels of staining in each of the areas of interest.

\section{Statistical analysis}

For daily food intake and body weight, differences between groups and day were analysed by repeated measures ANOVA. Leptin concentrations were analysed by Student's $t$-test. For all other experiments, differences between groups were analysed by two-way ANOVA. Where appropriate, ANOVA tests were followed by Bonferroni's Multiple Comparison post hoc test. For all the data analysed, the significance level was set at $P$ value $<0.05$.

\section{Declaration of interest}

The authors declare that there is no conflict of interest that could be perceived as prejudicing the impartiality of the research reported.

\section{Funding}

This work was supported by a grant from the Health Research Council of New Zealand.

\section{References}

Bates SH, Stearns WH, Dundon TA, Schubert M, Tso AW, Wang Y, Banks AS, Lavery HJ, Haq AK, Maratos-Flier E et al. 2003 STAT3 signalling is required for leptin regulation of energy balance but not reproduction. Nature 421 856-859. (doi:10.1038/nature01388)

Bennett E, McGuinness L, Gevers EF, Thomas GB, Robinson IC, Davey HW \& Luckman SM 2005 Hypothalamic STAT proteins: regulation of somatostatin neurones by growth hormone via STAT5b. Journal of Neuroendocrinology 17 186-194. (doi:10.1111/j.1365-2826.2005. 01296.x)

Bjorbaek C, Elmquist JK, Michl P, Ahima RS, van Bueren A, McCall AL \& Flier JS 1998 Expression of leptin receptor isoforms in rat brain microvessels. Endocrinology 139 3485-3491. (doi:10.1210/en.139.8. 3485)

Brown RS, Kokay IC, Herbison AE \& Grattan DR 2010 Distribution of prolactin-responsive neurons in the mouse forebrain. Journal of Comparative Neurology 518 92-102. (doi:10.1002/cne.22208)

Campfield LA, Smith FJ, Guisez Y, Devos R \& Burn P 1995 Recombinant mouse $\mathrm{OB}$ protein: evidence for a peripheral signal linking adiposity and central neural networks. Science 269 546-549. (doi:10.1126/science. 7624778) 
Coya R, Martul P, Algorta J, Aniel-Quiroga MA, Busturia MA \& Senaris R 2006 Effect of leptin on the regulation of placental hormone secretion in cultured human placental cells. Gynecological Endocrinology 22 620-626. (doi:10.1080/09513590601012587)

Darnell JE Jr 1997 STATs and gene regulation. Science 277 1630-1635. (doi:10.1126/science.277.5332.1630)

Faouzi M, Leshan R, Bjornholm M, Hennessey T, Jones J \& Munzberg H 2007 Differential accessibility of circulating leptin to individual hypothalamic sites. Endocrinology 148 5414-5423. (doi:10.1210/en. 2007-0655)

Flick AA, Brookfield KF, de la Torre L, Tudela CM, Duthely L \& GonzalezQuintero VH 2010 Excessive weight gain among obese women and pregnancy outcomes. American Journal of Perinatology 27 333-338. (doi:10.1055/s-0029-1243304)

Fuglsang J, Moller N, Ledet T \& Ovesen P 2008 Effects of glucose, glycerol, 3-hydroxybutyrate, insulin, and leptin on placental growth hormone secretion in placental explants. Hormone and Metabolic Research $\mathbf{4 0}$ 189-193. (doi:10.1055/s-2007-1004575)

Gavrilova O, Barr V, Marcus-Samuels B \& Reitman M 1997 Hyperleptinemia of pregnancy associated with the appearance of a circulating form of the leptin receptor. Journal of Biological Chemistry 272 30546-30551. (doi:10.1074/jbc.272.48.30546)

Gong Y, Ishida-Takahashi R, Villanueva EC, Fingar DC, Munzberg H \& Myers MG Jr 2007 The long form of the leptin receptor regulates STAT5 and ribosomal protein $\mathrm{S} 6$ via alternate mechanisms. Journal of Biological Chemistry 282 31019-31027. (doi:10.1074/jbc.M702838200)

Grattan DR 2001 The actions of prolactin in the brain during pregnancy and lactation. Progress in Brain Research 133 153-171.

Halaas JL, Gajiwala KS, Maffei M, Cohen SL, Chait BT, Rabinowitz D, Lallone RL, Burley SK \& Friedman JM 1995 Weight-reducing effects of the plasma protein encoded by the obese gene. Science $269543-546$. (doi:10.1126/science.7624777)

Ladyman SR 2007 Leptin resistance during pregnancy in the rat. Journal of Neuroendocrinology 20 269-277. (doi:10.1111/j.1365-2826.2007. 01628.x)

Ladyman SR \& Grattan DR 2004 Region-specific reduction in leptininduced phosphorylation of signal transducer and activator of transcription-3 (STAT3) in the rat hypothalamus is associated with leptin resistance during pregnancy. Endocrinology 145 3704-3711. (doi:10.1210/en. 2004-0338)

Ladyman SR \& Grattan DR 2005 Suppression of leptin receptor messenger ribonucleic acid and leptin responsiveness in the ventromedial nucleus of the hypothalamus during pregnancy in the rat. Endocrinology $\mathbf{1 4 6}$ 3868-3874. (doi:10.1210/en.2005-0194)

Ladyman SR, Tups A, Augustine RA, Swahn-Azavedo A, Kokay IC \& Grattan DR 2009 Loss of hypothalamic response to leptin during pregnancy associated with development of melanocortin resistance. Journal of Neuroendocrinology 21 449-456. (doi:10.1111/j.1365-2826. 2009.01862.x)

Ladyman SR, Augustine RA \& Grattan DR 2010 Hormone interactions regulating energy balance during pregnancy. Journal of Neuroendocrinology 22 805-817. (doi:10.1111/j.1365-2826.2010.02017.x)

McCowen KC, Chow JC \& Smith RJ 1998 Leptin signaling in the hypothalamus of normal rats in vivo. Endocrinology 139 4442-4447. (doi:10.1210/en.139.11.4442)

Mercer JG, Hoggard N, Williams LM, Lawrence CB, Hannah LT \& Trayhurn P 1996 Localization of leptin receptor mRNA and the long form splice variant $(\mathrm{Ob}-\mathrm{Rb})$ in mouse hypothalamus and adjacent brain regions by in situ hybridization. FEBS Letters 387 113-116. (doi:10.1016/ 0014-5793(96)00473-5)

Mistry AM \& Romsos DR 2002 Intracerebroventricular leptin administration reduces food intake in pregnant and lactating mice. Experimental Biology and Medicine 227 616-619.

Mistry AM, Swick AG \& Romsos DR 1997 Leptin rapidly lowers food intake and elevates metabolic rates in lean and ob/ob mice. Journal of Nutrition 127 2065-2072.

Morrison CD, White CL, Wang Z, Lee SY, Lawrence DS, Cefalu WT, Zhang ZY \& Gettys TW 2007 Increased hypothalamic protein tyrosine phosphatase 1B contributes to leptin resistance with age. Endocrinology 148 433-440. (doi:10.1210/en.2006-0672)
Mounzih K, Qiu J, Ewart-Toland A \& Chehab FF 1998 Leptin is not necessary for gestation and parturition but regulates maternal nutrition via a leptin resistance state. Endocrinology 139 5259-5262. (doi:10. 1210/en.139.12.5259)

Munzberg H 2008 Differential leptin access into the brain - a hierarchical organization of hypothalamic leptin target sites? Physiology \& Behavior 94 664-669. (doi:10.1016/j.physbeh.2008.04.020)

Munzberg H, Flier JS \& Bjorbaek C 2004 Region-specific leptin resistance within the hypothalamus of diet-induced obese mice. Endocrinology 145 4880-4889. (doi:10.1210/en.2004-0726)

Mutze J, Roth J, Gerstberger R \& Hubschle T 2007 Nuclear translocation of the transcription factor STAT5 in the rat brain after systemic leptin administration. Neuroscience Letters 417 286-291. (doi:10.1016/j. neulet.2007.02.074)

Oken E, Ning Y, Rifas-Shiman SL, Rich-Edwards JW, Olsen SF \& Gillman MW 2007 Diet during pregnancy and risk of preeclampsia or gestational hypertension. Annals of Epidemiology 17 663-668. (doi:10. 1016/j.annepidem.2007.03.003)

Paxinos G \& Franklin K 2004 The Mouse Brain in Stereotaxic Coordinates, 2nd edn. San Diego, CA, USA: Elsevier Academic Press.

Pelleymounter MA, Cullen MJ, Baker MB, Hecht R, Winters D, Boone T \& Collins F 1995 Effects of the obese gene product on body weight regulation in ob/ob mice. Science 269 540-543. (doi:10.1126/science. 7624776)

Peralta S, Carrascosa JM, Gallardo N, Ros M \& Arribas C 2002 Ageing increases SOCS-3 expression in rat hypothalamus: effects of food restriction. Biochemical and Biophysical Research Communications 296 425-428. (doi:10.1016/S0006-291X(02)00906-3)

Rizk NM, Stammsen D, Preibisch G \& Eckel J 2001 Leptin and tumor necrosis factor- $\alpha$ induce the tyrosine phosphorylation of signal transducer and activator of transcription proteins in the hypothalamus of normal rats in vivo. Endocrinology 142 3027-3032. (doi:10.1210/en. 142.7.3027)

Roy AF, Benomar Y, Bailleux V, Vacher CM, Aubourg A, Gertler A, Djiane J \& Taouis M 2007 Lack of cross-desensitization between leptin and prolactin signaling pathways despite the induction of suppressor of cytokine signaling 3 and PTP-1B. Journal of Endocrinology 195 341-350. (doi:10.1677/JOE-07-0321)

Soares MJ, Faria TN, Roby KF \& Deb S 1991 Pregnancy and the prolactin family of hormones: coordination of anterior pituitary, uterine, and placental expression. Endocrine Reviews 12 402-423. (doi:10.1210/ edrv-12-4-402)

Stothard KJ, Tennant PW, Bell R \& Rankin J 2009 Maternal overweight and obesity and the risk of congenital anomalies: a systematic review and meta-analysis. Journal of the American Medical Association 301 636-650. (doi:10.1001/jama.2009.113)

Tartaglia LA, Dembski M, Weng X, Deng N, Culpepper J, Devos R, Richards GJ, Campfield LA, Clark FT, Deeds J et al. 1995 Identification and expression cloning of a leptin receptor, OB-R. Cell 83 1263-1271. (doi:10.1016/0092-8674(95)90151-5)

Tomimatsu T, Yamaguchi M, Murakami T, Ogura K, Sakata M, Mitsuda N, Kanzaki T, Kurachi H, Irahara M, Miyake A et al. 1997 Increase of mouse leptin production by adipose tissue after midpregnancy: gestational profile of serum leptin concentration. Biochemical and Biophysical Research Communications 240 213-215. (doi:10.1006/bbrc.1997.7638)

Vaisse C, Halaas JL, Horvath CM, Darnell JE Jr, Stoffel M \& Friedman JM 1996 Leptin activation of Stat3 in the hypothalamus of wild-type and ob/ob mice but not db/db mice. Nature Genetics 14 95-97. (doi:10. 1038/ng0996-95)

White CL, Whittington A, Barnes MJ, Wang Z, Bray GA \& Morrison CD 2009 HF diets increase hypothalamic PTP1B and induce leptin resistance through both leptin-dependent and -independent mechanisms. American Journal of Physiology. Endocrinology and Metabolism 296 E291-E299. (doi:10.1152/ajpendo.90513.2008)

Received 28 March 2012

First decision 23 April 2012

Revised manuscript received 8 May 2012

Accepted 10 May 2012 